\title{
Relation between respiratory symptoms, pulmonary function and peak flow variability in adults
}

\author{
H M Boezen, J P Schouten, D S Postma, B Rijcken
}

\begin{abstract}
Background - A study was carried out to determine whether subjects with respiratory symptoms are more likely to have impaired lung function or increased airway lability, and to quantify these relationships in a population of adults.

Methods - Data were collected from 511 participants (aged 20-70 years) from the Dutch part of the European Community Respiratory Health Survey (ECRHS). The symptoms analysed were: wheeze, dyspnoea $\geqslant$ grade 3 , nocturnal dyspnoea, cough and phlegm, and history of allergy. Lung function was measured by peak expiratory flow (PEF) and forced expiratory volume in one second $\left(\mathrm{FEV}_{1}\right)$. PEF variability was used as an index for bronchial lability.

Results - Both FEV 1 and PEF were decreased with increasing numbers of symptoms. Subjects with one symptom had an increased risk of having an $\mathrm{FEV}_{1}$ value of $<70 \%(O R=4 \cdot 2)$ and this risk increased with an increasing number of symptoms. Subjects with three or more symptoms had an increased risk of having a PEF value of $<70 \%$, a diurnal variation in PEF of $>10 \%$ (both $O R=4 \cdot 4$ ), and an increased risk of high between day variation $(O R=6 \cdot 6)$. Conclusions - Subject-reported symptoms are related to impaired lung function and to increased variability of peak flow.

(Thorax 1995;50:121-126)
\end{abstract}

Keywords: pulmonary function, respiratory symptoms, peak expiratory flow.

Department of

Epidemiology and

Statistics, University of Groningen, 9713AV Groningen, The Netherlands

H M Boezen

J P Schouten

B Rijcken

Department of

Pulmonology,

University Hospital

Groningen,

The Netherlands

D S Postma

Reprint requests to: Dr B Rijcken.

Received 2 June 1994

Returned to authors

10 August 1994

Revised version received

6 October 1994

Accepted for publication

1 November 1994
A considerable proportion of the adult population in western society is affected by chronic obstructive lung disease. Depending on the definition, $5-10 \%$ of younger adults (20-45 years of age) suffer from mild to severe asthma. In older age groups symptoms such as chronic expectoration are common. In the elderly prevalence rates are high ${ }^{12}$ and increase with age. In several population studies of subjects above 60 years $30-60 \%$ reported one or more chronic respiratory symptom such as chronic cough or phlegm, dyspnoea, persistent wheeze, or chest tightness. Spirometric tests often reveal severe impairment of lung function and the clinical prognosis, in terms of mortality risk, is unfavourable for these subjects. ${ }^{34}$

Symptoms are generally the primary reason for consultation with a doctor. The general practitioner will restrict diagnostic activities to a medical history and examination. In most cases spirometric tests will not be performed. Chronic respiratory symptoms are associated with diminished lung function and increased airway lability. ${ }^{5-7}$ Once lung function impairment has been quantified by measurement of the $\mathrm{FEV}_{1}$ or PEF variability, any further changes - such as decline in lung function or improvement as a result of interventions - can be monitored. Although simple lung function equipment is becoming increasingly available, it remains uncertain for which cases spirometric testing is useful. The same is true for the assessment of airway lability by repeated peak flow measurements at home.

We studied a random sample of adults in a wide age range (20-70), collecting information on respiratory symptoms, spirometric parameters, and peak flow measurements. The aim of the study was to investigate whether subjects with respiratory symptoms are more likely to have impaired lung function or increased airway lability, and whether this association is stronger in older subjects.

\section{Methods}

DATA COLLECTION AND ANALYSES

In the city of Groningen, The Netherlands, an age stratified random sample of 750 men and 750 women aged $20-70$ were invited to participate in a respiratory survey. Data on respiratory symptoms and smoking habits were collected by means of the standardised questionnaire of the ECRHS. ${ }^{8}$ Symptoms were defined as: (1) wheezing or whistling without having a cold at any time in the last 12 months (wheeze); (2) shortness of breath when walking with other people of their own age on level ground (dyspnoea $\geqslant$ grade 3 ); (3) woken up by an attack of shortness of breath at any time in the last 12 months (nocturnal dyspnoea); (4) cough, usually first thing in the morning, during the day or at night in the winter (cough); (5) phlegm, usually first thing in the morning, during the day or at night in the winter (phlegm); (6) presence of a runny or stuffy nose or itchy watering eyes, cough, wheeze or sneeze, tightness in the chest, or shortness of breath when near animals or trees, grass, flowers or with increased levels of pollen (history of allergy). Subjects who denied having any of these symptoms were considered to be asymptomatic and were further described as the "no symptom" group. The cumulative amount of cigarettes ever smoked was cal- 
culated and expressed in pack-years ( 1 packyear $=25$ cigarettes per day for one year).

Participants were given a mini-Wright peak flow meter (Clement Clarke International Ltd, London, UK) and were instructed in its use by a trained technician. ${ }^{910}$ Participants performed PEF measurements at home every morning on rising and again every afternoon between $5.00 \mathrm{pm}$ and $6.00 \mathrm{pm}$, before dinner, for seven successive days. The highest values of the morning and the afternoon were used in the analyses. If subjects were receiving bronchodilator treatment PEF values had to be measured before its use. Every peak flow meter was checked by a trained technician before distribution and upon return.

PEF variability was expressed in two ways: (1) diurnal PEF variation (amplitude \% mean) defined as: (highest PEF - lowest PEF)/(mean value of the two) $\times 100 \%$ over a minimum of five days ${ }^{11}$; and (2) between day PEF variation defined as: standard deviation of a minimum of five mornings as a percentage of the mean morning PEF (SD\% mean morning PEF). ${ }^{12}$

The $\mathrm{FEV}_{1}$ was measured using the ECRHS lung function protocol ${ }^{8}$ that meets the American Thoracic Society guidelines. ${ }^{1314}$ Measurements were performed with a dry seal Morgan Spiroflow Ds12 (PK Morgan Ltd, UK). Age and height were centred to the mean (mc). To describe the dependencies of FEV and PEF on age and height in this population several models were investigated, especially with regard to the age variable (entered into the model as, for example, age ${ }^{2}$ or as the reciprocal of age). The linear model fitted the best (65\% explained variance). Prediction equations were based on this linear model. The predicted (pred) $\mathrm{FEV}_{1}$ and PEF for this population were:

$\mathrm{FEV}_{1}$ pred men $=(4.33+4.46 \times \mathrm{mc}$ height $-0.033 \times \mathrm{mc}$ age) $[\mathrm{RSD}=0.58]^{15}$

$\mathrm{FEV}_{1}$ pred women $=(3 \cdot 18+3 \cdot 57 \times \mathrm{mc}$ height $-0.024 \times \mathrm{mc}$ age) $[\mathrm{RSD}=0.38$ ]

PEF pred men $=(600 \cdot 1+429 \cdot 9 \times \mathrm{mc}$ height $-1.571 \times \mathrm{mc}$ age) $[\mathrm{RSD}=76 \cdot 9]$

PEF pred women $=(446 \cdot 7+140 \cdot 8 \times \mathrm{mc}$ height $-2 \cdot 152 \times \mathrm{mc}$ age) $[\mathrm{RSD}=60 \cdot 8]$

$\mathrm{FEV}_{1}$ and morning PEF values were expressed as percentage of predicted values, ${ }^{16} \mathrm{a}$ value of less than $70 \%$ predicted being considered abnormal. Values below these limits were defined as "low FEV" and "low morning PEF" respectively. Odds ratios for "low $\mathrm{FEV}_{1}$ " and "low PEF" were estimated according to
Table 1 Mean (SD) population characteristics stratified by sex

\begin{tabular}{|c|c|c|}
\hline Variables & $\begin{array}{l}\text { Men } \\
(n=265)\end{array}$ & $\begin{array}{l}\text { Women } \\
(n=246)\end{array}$ \\
\hline $\begin{array}{l}\text { Age (years) } \\
\text { Height (m) } \text { FEV }(1) \\
\text { Morning PEF (1/min) } \\
\text { Diurnal PEF variation } \\
(\%) t \\
\text { Between day PEF } \\
\text { variation (\%)t } \\
\text { Pack-years }\end{array}$ & $\begin{array}{l}47(14) \\
1.79(0.07)^{*} \\
4 \cdot 2(1 \cdot 0)^{* *} \\
582(96)^{* *} \\
\\
3.47(1.95)^{* *} \\
\\
2.57(1.92)^{* *} \\
15.2(16.5)^{*}\end{array}$ & $\begin{array}{l}44(15) \\
1.66(0.06) \\
3 \cdot 1(0 \cdot 7) \\
435(78) \\
\\
3.89(2 \cdot 13) \\
\\
3 \cdot 16(1.94) \\
8.0(13.4)\end{array}$ \\
\hline
\end{tabular}

$\mathrm{FEV}_{1}=$ forced expiratory volume in one second; $\mathrm{PEF}=$ peak expiratory flow.

* Significant difference between men and women $\left(\chi^{2}\right.$ test or test, $\mathrm{p}<0.05$ ).

** Significant difference between men and women (ANCOVA by multiple regression method with adjustment for age, height and pack-years, $\mathrm{p}<0.05$ ).

† Diurnal PEF variation, between day PEF variation and standard deviations are expressed in geometric values (transformed back after calculations on $\log _{10}$ transformed data).

the number of respiratory symptoms (logistic regressions with adjustment for gender, age, height, pack-years). Odds ratios were considered significant if the $95 \%$ confidence interval did not include the value 1 .

Diurnal variation in PEF of more than $10 \%$ was considered to be abnormal. Above this limit diurnal variation in PEF was defined as "high diurnal PEF variation". Between day variation in PEF above 8\% (95th percentile) was considered to be abnormal and defined as "high between day PEF variation". Logistic regression was performed to estimate the odds ratios on either of these two forms of high PEF variability depending on the number of respiratory symptoms (with adjustment for gender, age, height, and pack-years).

Distributions of $\mathrm{FEV}_{1}$, PEF or PEF variability were inspected visually by normal probability plots of the standardised residuals of the total population and tested formally by the Kolmogorov-Smirnov test. Parametric tests were used to analyse normal distributions and, for skewed distributions, log transformations were performed to achieve normalisation. Analyses were performed on these log transformed data. Means were transformed back to normal units (geometric means) unless otherwise stated. Differences between means were tested using $t$ tests or analyses of covariance by multiple regression method (ANCOVA). Differences between proportions were tested using $\chi^{2}$ tests. All tests were two sided and $p$ values of $<0.05$ were considered significant. To investigate the association of symptoms with lung

Table 2 Respiratory symptoms stratified by sex and age

\begin{tabular}{|c|c|c|c|c|c|c|}
\hline & \multicolumn{3}{|l|}{ Men } & \multicolumn{3}{|l|}{ Women } \\
\hline & $\begin{array}{l}20-44 \text { years } \\
(n=124(46 \cdot 8 \%))\end{array}$ & $\begin{array}{l}45-69 \text { years } \\
(n=141(53 \cdot 2 \%))\end{array}$ & $\begin{array}{l}\text { Total } \\
(n=265(51 \cdot 9 \%))\end{array}$ & $\begin{array}{l}20-44 \text { years } \\
(n=124(50 \cdot 4 \%))\end{array}$ & $\begin{array}{l}45-69 \text { years } \\
(n=122(49 \cdot 6 \%))\end{array}$ & $\begin{array}{l}\text { Total } \\
(n=246(48 \cdot 1 \%))\end{array}$ \\
\hline $\begin{array}{l}\text { Wheeze } \\
\text { Dyspnoea शgrade } 3 \\
\text { Nocturnal dyspnoea } \\
\text { Cough } \\
\text { Phlegm } \\
\text { History of allergy* }\end{array}$ & $\begin{aligned} 14 & (11 \cdot 3) \\
9 & (7 \cdot 3)^{* *} \\
3 & (2 \cdot 4) \\
6 & (4 \cdot 8) \\
4 & (3 \cdot 2) \\
42 & (33 \cdot 9)\end{aligned}$ & $\begin{aligned} & 22(15 \cdot 6) \\
& 28(19 \cdot 9) \\
& 7(5 \cdot 0) \\
& 10(7 \cdot i) \\
& 12(8 \cdot 5) \\
& 33(23 \cdot 4)\end{aligned}$ & $\begin{array}{l}36(13 \cdot 6) \\
37(14 \cdot 0) \\
10(3 \cdot 8) \\
16(6 \cdot 0) \\
16(6 \cdot 0) \\
75(28 \cdot 3)\end{array}$ & $\begin{array}{c}16(12 \cdot 9) \\
13(10 \cdot 5)^{* *} \\
4(3 \cdot 2)^{* *} \\
5(4 \cdot 0) \\
3(2 \cdot 4)^{* *} \\
53(42 \cdot 7)\end{array}$ & $\begin{aligned} & 13(10 \cdot 7) \\
& 31(25 \cdot 4) \\
& 12(9 \cdot 8) \\
& 8(6 \cdot 6) \\
& 10(8 \cdot 2) \\
& 47(38 \cdot 5)\end{aligned}$ & $\begin{array}{c}29(11 \cdot 8) \\
44(17 \cdot 9) \\
16(6 \cdot 5) \\
13(5 \cdot 3) \\
13(5 \cdot 3) \\
100(40 \cdot 7)\end{array}$ \\
\hline $\begin{array}{l}0 \text { symptom } \\
1 \text { symptom } \\
2 \text { symptoms } \\
\geqslant 3 \text { symptoms }\end{array}$ & $\begin{array}{c}71(57 \cdot 3) \\
37(29 \cdot 8) \\
9(7 \cdot 3) \\
7(5 \cdot 6)\end{array}$ & $\begin{array}{l}72(51 \cdot 1) \\
41(29 \cdot 1) \\
17(12 \cdot 1) \\
11(7 \cdot 8)\end{array}$ & $\begin{array}{c}143(54 \cdot 0) \\
78(29 \cdot 4) \\
26(9 \cdot 8) \\
18(6 \cdot 8)\end{array}$ & $\begin{array}{c}64(51.6) \\
39(31.5) \\
13(10.5) \\
8(6.5)\end{array}$ & $\begin{array}{l}54(44 \cdot 3) \\
39(32 \cdot 0) \\
16(13 \cdot 1) \\
13(10 \cdot 7)\end{array}$ & $\begin{array}{c}118(50 \cdot 0) \\
78(31 \cdot 7) \\
29(11 \cdot 8) \\
21(8 \cdot 5)\end{array}$ \\
\hline
\end{tabular}

* Significant difference between men and women; ${ }^{* *}$ significant differences between age groups by sex $\left(\chi^{2}\right.$ tests, $\left.p<0 \cdot 05\right)$. 


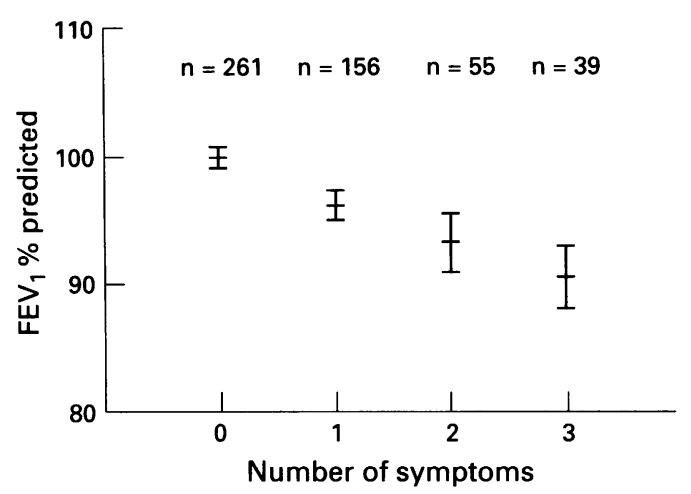

Figure 1 Mean (SE) forced expiratory volume in one second $\left(F E V_{1}\right)$ as percentage of predicted according to number of symptoms.

function and age, stepwise multiple regression analyses were performed including interaction terms of the separate symptoms with age. All analyses were performed with the SPSS/PC ${ }^{+}$ V4.0 package. This study was part of the European Community Respiratory Health Survey, a multicentre study on respiratory health. ${ }^{8}$

\section{Results}

Of the 1500 subjects who were invited to participate in the ECRHS, $836(56 \%)$ responded. Responders were more likely to be older and to have symptoms than non-responders, but these differences were small and not significant. PEF measurements were made in a group randomly chosen from these responders. Of the 579 subjects who were randomly asked to join the current study 573 (99\%) agreed to participate. ${ }^{17}$ All had performed lung function testing and completed the questionnaire. A completely filled in and readable PEF recording form was received from 520 subjects $(90 \cdot 8 \%)$ and their data were analysed. The group who failed to return a properly filled in form $(n=$ 53) did not differ from the analysed group in age and sex distributions, but contained relatively more current smokers and less never smokers $\left(\chi^{2}\right.$ test, $\left.\mathrm{p}<0.001\right)$. As the mean PEF values of the study population on the first day were significantly lower than on the other days, the data from day 1 were excluded from the analyses. After this exclusion, nine subjects had less than the required five days and their data were not analysed. Data of 511 subjects (265

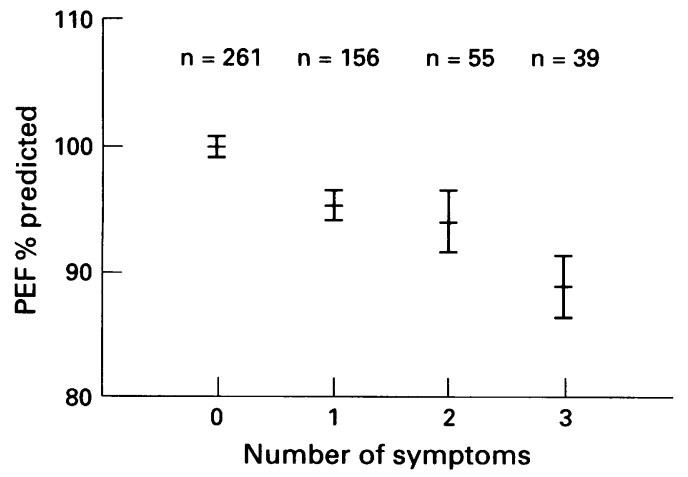

Figure 2 Mean (SE) peak expiratory flow (PEF) as percentage of predicted according to number of symptoms.

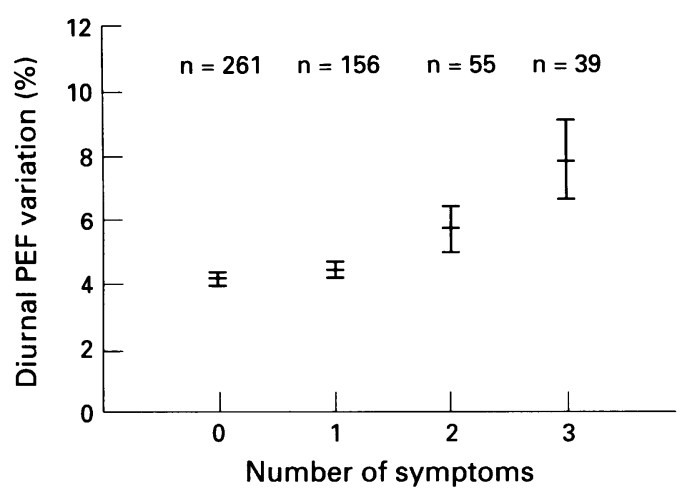

Figure 3 Mean (SE) diurnal variation in peak expiratory flow (PEF) according to number of symptoms.

men and 246 women aged $20-70$ ) were used for the analyses. The population characteristics are shown in table 1. Detailed data on the distributions of PEF flow have been described elsewhere. ${ }^{17}$

Approximately $50 \%$ of the total study population reported one or more of the following symptoms (table 2 ): wheeze, dyspnoea $\geqslant$ grade 3 , nocturnal dyspnoea, cough or phlegm, allergic symptoms. One symptom was reported by $30 \%$, two symptoms were reported by $10 \%$, and three or more symptoms by approximately $8 \%$ of the subjects. Women reported slightly more respiratory symptoms than men. The frequency of the respiratory symptoms is shown in table 2 , stratified by age and sex.

Mean $\mathrm{FEV}_{1} \%$ predicted was significantly different in the various symptom groups (fig 1 ), being highest in the "no symptom" group and lowest in those who reported $\geqslant 3$ symptoms ( $p<0.001$ adjusted for sex, age, height, and pack-years). Similar significant differences between symptom groups were found for PEF $\%$ predicted (fig 2) ( $\mathrm{p}<0.0001$ adjusted for sex, age, height, and pack-years).

There was a positive association between the number of symptoms and the magnitude of the diurnal PEF variation, with the highest mean variation in subjects reporting $\geqslant 3$ symptoms and the lowest mean variation in the "no symptom" group (fig 3) ( $p<0.001$ adjusted for sex, age, height, and pack-years). The same positive association was found between the number of reported symptoms and the between day variation in PEF (fig 4).

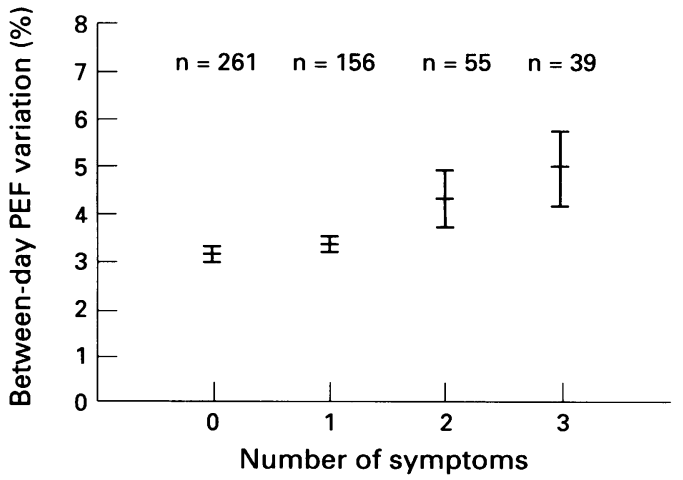

Figure 4 Mean (SE) between day variation in peak expiratory flow (PEF) according to number of symptoms. 
Table 3 Regression coefficients $\beta$ (with standard error (SE) and $p$ values) resulting from multiple regression analyses with respiratory symptoms as independent variables and FEV,$P E F$, diurnal PEF variation and between day PEF variation respectively, as dependent variables, adjusted for packyears, sex, mean centred age, mean centred height, and other respiratory symptoms

\begin{tabular}{|c|c|c|c|c|c|c|c|c|c|c|c|c|}
\hline \multirow[t]{2}{*}{ Variable } & \multicolumn{3}{|c|}{$F E V_{1}(l)$} & \multicolumn{3}{|c|}{$P E F(l / m i n)$} & \multicolumn{3}{|c|}{ Diurnal PEF variation $\dagger$} & \multicolumn{3}{|c|}{$\begin{array}{l}\text { Between day PEF } \\
\text { variation } \dagger\end{array}$} \\
\hline & $\beta$ & $S E$ & $p$ & $\beta$ & $S E$ & $p$ & $\beta$ & $S E$ & $p$ & $\beta$ & $S E$ & $p$ \\
\hline $\begin{array}{l}\text { Wheeze } \\
\text { Dyspnoea } \geqslant \text { grade } 3 \\
\text { Nocturnal dyspnoea } \\
\text { Cough } \\
\text { Phlegm } \\
\text { History of allergy }\end{array}$ & $\begin{array}{r}-0 \cdot 18 \\
-0.13 \\
-0.36 \\
-0.07 \\
0.20 \\
0.00\end{array}$ & $\begin{array}{l}0 \cdot 07 \\
0 \cdot 07 \\
0 \cdot 11 \\
0 \cdot 11 \\
0 \cdot 11 \\
0 \cdot 05\end{array}$ & $\begin{array}{l}0.01 \\
<0.05 \\
0.00 \\
\text { NS } \\
\text { NS } \\
\text { NS }\end{array}$ & $\begin{array}{r}-15 \cdot 02 \\
-2 \cdot 35 \\
-43 \cdot 48 \\
-48 \cdot 34 \\
20 \cdot 54 \\
-11 \cdot 56\end{array}$ & $\begin{array}{r}10 \cdot 39 \\
9 \cdot 53 \\
16 \cdot 07 \\
15 \cdot 70 \\
16 \cdot 00 \\
7 \cdot 09\end{array}$ & $\begin{array}{l}\text { NS } \\
\text { NS } \\
0 \cdot 01 \\
0 \cdot 00 \\
\text { NS } \\
\text { NS }\end{array}$ & $\begin{array}{r}0.05 \\
0 \cdot 02 \\
0 \cdot 22 \\
0 \cdot 20 \\
-0 \cdot 04 \\
0 \cdot 01\end{array}$ & $\begin{array}{l}0.04 \\
0.04 \\
0.06 \\
0.06 \\
0.06 \\
0.03\end{array}$ & $\begin{array}{l}\text { NS } \\
\text { NS } \\
0 \cdot 00 \\
0 \cdot 00 \\
\text { NS } \\
\text { NS }\end{array}$ & $\begin{array}{r}0.06 \\
0.01 \\
0.23 \\
0.13 \\
-0.10 \\
-0.02\end{array}$ & $\begin{array}{l}0.04 \\
0.04 \\
0.06 \\
0.06 \\
0.06 \\
0.03\end{array}$ & $\begin{array}{l}\text { NS } \\
\text { NS } \\
0 \cdot 00 \\
<0 \cdot 05 \\
\text { NS } \\
\text { NS }\end{array}$ \\
\hline $\begin{array}{l}\text { Age } \\
\text { Height } \\
\text { Sex (F:M) } \\
\text { Pack-years } \\
\text { Intercept }\end{array}$ & $\begin{array}{r}-0.03 \\
4.72 \\
-1.14 \\
-0.01 \\
6.07\end{array}$ & $\begin{array}{l}0.00 \\
0.35 \\
0.05 \\
0.00 \\
0.16\end{array}$ & $\begin{array}{l}0.00 \\
0.00 \\
0.00 \\
0.00 \\
0.00\end{array}$ & $\begin{array}{c}-1.53 \\
331 \cdot 0 \\
-154.5 \\
-1.20 \\
864.3\end{array}$ & $\begin{array}{c}0.26 \\
50 \cdot 6 \\
6 \cdot 7 \\
0 \cdot 24 \\
23 \cdot 7\end{array}$ & $\begin{array}{l}0.00 \\
0.00 \\
0.00 \\
0.00 \\
0.00\end{array}$ & $\begin{array}{l}0.003 \\
0.01 \\
0.05 \\
0.002 \\
-0.03\end{array}$ & $\begin{array}{l}0.00 \\
0.03 \\
0.03 \\
0.00 \\
0 \cdot 10\end{array}$ & $\begin{array}{l}0 \cdot 00 \\
\text { NS } \\
\text { NS } \\
\text { NS } \\
\text { NS }\end{array}$ & $\begin{array}{c}0.003 \\
-0.02 \\
0 \cdot 11 \\
0.002 \\
-0.06\end{array}$ & $\begin{array}{l}0.00 \\
0.03 \\
0.03 \\
0.00 \\
0.09\end{array}$ & $\begin{array}{l}0.00 \\
\text { NS } \\
0 \cdot 00 \\
0 \cdot 01 \\
\text { NS }\end{array}$ \\
\hline RSD & 0.49 & & & $71 \cdot 0$ & & & $0 \cdot 29$ & & & $0 \cdot 27$ & & \\
\hline
\end{tabular}

RSD = residual standard deviation.

† Analyses have been performed on the log transformed values of diurnal PEF variation and between day PEF variation.

Diurnal and between day variation in PEF were both associated with age (with greater values at older ages), pack-years, and sex (table 3). To quantify the association of the separate respiratory symptoms with PEF variability and $\mathrm{FEV}_{1}$ and $\mathrm{PEF}$, multiple regressions were performed with simultaneous adjustments for age, height, sex, pack-years, and each of the other symptoms (table 3 ). Subjects reporting wheeze had significantly lower $\mathrm{FEV}_{1}$ than subjects without this symptom $(\beta=-0 \cdot 18 ; \mathrm{p}<0 \cdot 01)$. Nocturnal dyspnoea was associated with significantly higher diurnal and between day variation in PEF, and lower PEF and $\mathrm{FEV}_{1}$ $(\mathrm{p}<0.01)$ (table 3$)$. Cough was associated with higher diurnal and between day variation in PEF $(\beta=0.20$ and $\beta=0.13$ respectively; $p<0.05)$ and a lower morning PEF $(\beta=$ $-48.34 ; p<0.005)$. Dyspnoea $\geqslant$ grade 3 had a significant negative association with the $\mathrm{FEV}_{1}$ $(\beta=-0.13 ; p<0 \cdot 05)$. Phlegm and history of allergy were neither significantly associated with PEF variability, nor with PEF or FEV (table 3).

To estimate the odds ratios for "low PEF", "low $\mathrm{FEV}_{1}$ ", "high diurnal PEF variation", and "high between day PEF variation" in association with the number of respiratory symptoms logistic regressions were performed (table 4). Subjects who reported having three or more symptoms had greater odds for low morning PEF (OR $=4 \cdot 4)$, low $\mathrm{FEV}_{1}(\mathrm{OR}=7 \cdot 6)$, high diurnal PEF variation $(O R=4 \cdot 4)$, and high between day $P E F$ variation $(O R=6 \cdot 6)$ than those with no symptoms (table 4). The odds ratio for low $\mathrm{FEV}_{1}$ was at least four times greater in subjects with any symptom than in those without symptoms.
Age modified the association between nocturnal dyspnoea and between day variation in PEF $(\beta=0.002, p<0.005)$. Older age groups with nocturnal dyspnoea thus had a greater variation in PEF between days than might be expected based on age, height, sex, and packyears. Adjustment for initial PEF did not change this significant interaction. The PEF had a significant negative interaction with the presence of cough and age $(\beta=-1 \cdot 34$, $\mathrm{p}<0.001)$. Thus, in older patients cough was associated with lower PEF values than might have been expected on the basis of age, height, sex, and pack-years. This interaction term remained significant after adjustment for initial PEF.

\section{Discussion}

These results show that approximately $50 \%$ of a random population of adults reported one or more respiratory symptoms. Older people tended to report symptoms more often and the proportion of subjects with two or more symptoms increased with age. On average, subjects with wheeze, dyspnoea $\geqslant$ grade 3 , and nocturnal dyspnoea had significantly lower levels of $\mathrm{FEV}_{1}$ (\% predicted). Subjects with nocturnal dyspnoea and cough had significantly lower levels of PEF (\% predicted). With increasing numbers of symptoms the mean levels of $\mathrm{FEV}_{1}$ and PEF were lower. On average, subjects with two or more symptoms had a seven times greater risk of significant impairment of $\mathrm{FEV}_{1}$ ( $<70 \%$ predicted). Subjects with three or more symptoms had a four times higher risk of a PEF of $<70 \%$ predicted and a high diurnal PEF variation $(>10 \%)$ than

Table 4 Odds ratios (OR) estimated from logistic regression with $F E V_{1}<70 \%$ predicted $F E V_{1}$, morning $P E F<70 \%$ predicted morning PEF, diurnal PEF variation $>10 \%$ and between day $P E F$ variation $>8 \%$ as dependent variables and the number of respiratory symptoms compared with no respiratory symptoms, mean centred age, mean centred height, pack-years, and sex as independent variables

\begin{tabular}{|c|c|c|c|c|c|c|c|c|c|}
\hline \multirow[t]{2}{*}{ Variable } & \multirow[t]{2}{*}{$n$} & \multicolumn{2}{|c|}{$\begin{array}{l}F E V_{1}<70 \% \\
\text { predicted } \\
(n=20(3 \cdot 9 \%))\end{array}$} & \multicolumn{2}{|c|}{$\begin{array}{l}\text { Morning PEF }<70 \% \\
\text { predicted } \\
(n=22(4 \cdot 3 \%))\end{array}$} & \multicolumn{2}{|c|}{$\begin{array}{l}\text { Diurnal PEF variation } \\
>10 \% \\
(n=28(5 \cdot 5 \%))\end{array}$} & \multicolumn{2}{|c|}{$\begin{array}{l}\text { Between day PEF } \\
\text { variation }>8 \% \\
(n=25(4.9 \%))\end{array}$} \\
\hline & & $O R$ & $95 \% C I$ & $O R$ & $95 \% C I$ & $O R$ & $95 \% C I$ & $O R$ & $95 \% C I$ \\
\hline $\begin{array}{l}1 \text { symptom } \\
2 \text { symptoms } \\
\geqslant 3 \text { symptoms }\end{array}$ & $\begin{array}{r}156 \\
55 \\
39\end{array}$ & $\begin{array}{l}4 \cdot 2 \\
9 \cdot 0 \\
7 \cdot 6\end{array}$ & $\begin{array}{l}1 \cdot 1 \text { to } 16 \cdot 6 \\
1 \cdot 8 \text { to } 43 \cdot 7 \\
1 \cdot 1 \text { to } 52 \cdot 8\end{array}$ & $\begin{array}{l}1 \cdot 4 \\
2 \cdot 7 \\
4 \cdot 4\end{array}$ & $\begin{array}{l}0.4 \text { to } 4.6 \\
0.9 \text { to } 10.6 \\
1.1 \text { to } 18.6\end{array}$ & $\begin{array}{l}1 \cdot 0 \\
1 \cdot 8 \\
4 \cdot 4\end{array}$ & $\begin{array}{l}0.1 \text { to } 3 \cdot 0 \\
0.5 \text { to } 6 \cdot 2 \\
1 \cdot 2 \text { to } 16 \cdot 0\end{array}$ & $\begin{array}{l}1 \cdot 4 \\
2 \cdot 5 \\
6 \cdot 6\end{array}$ & $\begin{array}{l}0.4 \text { to } 4.4 \\
0.6 \text { to } 10.7 \\
1.9 \text { to } 22.5\end{array}$ \\
\hline
\end{tabular}

$\mathrm{FEV}_{1}$ = forced expiratory volume in one second; $\mathrm{PEF}$ = peak expiratory flow. 
asymptomatic subjects. The risk of a high variation in between day PEF (>8\%) increased by six times in subjects with three or more symptoms. Airway lability intensified with increasing age and with higher numbers of reported symptoms, and appeared to be significantly greater in subjects with nocturnal dyspnoea and cough.

Several studies have investigated the predictive value of respiratory symptoms for (annual) change in $\mathrm{FEV}_{1}$ in children ${ }^{18}{ }^{19}$ or adults. ${ }^{20-22}$ Jaakkola and coworkers followed a population of young adults for a period of eight years and found larger negative annual changes in $F_{E V}$ in subjects who reported new onset of wheeze or dyspnoea. ${ }^{20}$ Another longitudinal population study performed by Sherman and coworkers reported an accelerated loss in $\mathrm{FEV}_{1}$ in men with cough and phlegm and women with cough alone. ${ }^{21}$ Krzyzanowski and coworkers ${ }^{22}$ described lower levels of FEV ${ }_{1}$ if the symptoms "attacks of breathlessness" and "exertional dyspnoea" ("dyspnoea $\geqslant$ grade 3 ") were present, independent of other respiratory symptoms. Like Krzyzanowski, we found significantly lower values for $\mathrm{FEV}_{1}$ when dyspnoea $\geqslant$ grade 3 was present, but also when wheeze or nocturnal dyspnoea were reported. Besides the association of nocturnal dyspnoea with a lower level of $\mathrm{FEV}_{1}$, we found this symptom to be associated with a lower PEF and higher diurnal and between day variation in PEF. Brand and coworkers ${ }^{11}$ reported the same association with higher values of diurnal PEF variation in a group of patients with respiratory diseases, specifically in those patients with asthmatic bronchitis and asthma.

No significant association was found between diurnal variation in PEF and phlegm. This finding is in accordance with results presented by Neukirch and coworkers. ${ }^{23}$ In contrast to Neukirch, we did find a positive association between the presence of cough and the magnitude of the diurnal variation in PEF. This difference in results may be explained by the fact that our population consisted of a random sample of adults in a wider age range than the French study which consisted of younger individuals.

After adjustment for other respiratory symptoms, history of allergy was not associated with either airway lability or lung function. Nevertheless, we did not exclude history of allergy from the analyses because it is an often reported, well recognised, and specific symptom. In addition, the amount of explained variation in PEF, $\mathrm{FEV}_{1}$, and PEF variability was increased when history of allergy was included in the model. A history of allergy therefore appears to have additional predictive value in the presence of other symptoms.

This study was performed to determine whether the presence of respiratory symptoms was associated with impairment of lung function. The symptoms we asked for were prevalent in this study population. More than any specific symptom, the presence of several symptoms appeared to be strongly associated with significant impairment of lung function. This association did not change when those subjects with doctor diagnosed asthma ( $\mathrm{n}=$ 39) were excluded.

Significant impairment of lung function was defined as an $\mathrm{FEV}_{1}$ of $<70 \%$ predicted. As the dependency of lung function on age is curvilinear, this may result in an overestimation of the proportion of older subjects with an $\mathrm{FEV}_{1}$ of $<70 \%$ predicted. However, we investigated several models in relation to the age variable and found that the linear model fitted the best. For the current population an $\mathrm{FEV}_{1}$ of $<70 \%$ therefore seems to be a legitimate definition of significant impairment of lung function for the whole group.

One cannot be sure of the underlying process responsible for the altered relationship between nocturnal dyspnoea and cough, on the one hand, and lung function in the older subjects on the other. It is possible that cardiac disease, which frequently occurs with increasing age, affects this relationship. However, the results did not change when the variable "use of heart medication" was included in the analyses, nor when the subjects who reported the use of heart medication were excluded from the analyses. This does not permit conclusions, however, as we did not perform clinical diagnostic measurements to quantify cardiac disease when subjects reported use of heart medication. Further studies on the effects of comorbidity on lung function with increasing age are required.

Because the current analyses were performed on data collected in a cross-sectional study, no conclusions can be drawn on whether respiratory symptoms preceded or were a result of lower $\mathrm{FEV}_{1}$ or PEF or increased airway lability.

This study shows than an increasing number of symptoms occur with increasing age. A higher risk of significant impairment of $\mathrm{FEV}_{1}$ is present for subjects with two symptoms or more. General practitioners should therefore ask subjects about symptoms such as nocturnal dyspnoea and cough when any respiratory symptom is mentioned, especially if subjects are elderly. As adaptation to respiratory symptoms in elderly subjects appears to be common, ${ }^{24}$ general practitioners should be particularly alert to every patient who reports such symptoms when attending his or her practice. The presence of more than one respiratory symptom in elderly patients should alert the practitioner to the possibility of chronic impairment of lung function.

This study was supported by grants from the Ministry of Wellbeing, Public Health and Culture, The Netherlands, Jan Kornelis de Cock Foundation, Groningen, The Netherlands, and the Netherlands Asthma Fund, Grant Number 92.12. Glaxo Pharmaceuticals kindly provided the peak flow meters.

1 Caird FI, Akhtar AJ. Chronic respiratory disease in the elderly. Thorax 1972;27:764-8

Dow L, Coggon D, Osmond C, Holgate ST. A population survey of respiratory symptoms in the elderly. Eur Respir f 1991;4:267-72.

3 Cook NR, Evans DA, Scherr PA, Speizer FE, Taylor JO, Hennekens $\mathrm{CH}$. Peak expiratory flow rate and 5 -year mortality in an elderly population. Am f Epidemiol 1991; 133:784-94.

4 Milne JS. Longitudinal respiratory studies in older people. Thorax 1978;33:547-54.

5 Hargreave FE, Ryan G, Thomson NC, O'Byrne PM, La- 
timer $\mathrm{K}$, Juniper EF, et al. Bronchial responsiveness to histamine or methacholine in asthma: measurement and clinical significance. $\mathcal{F}$ Allergy Clin Immunol 1981;68:34755.

6 Rijcken B, Schouten JP, Weiss ST, Speizer FE, Van der Lende $R$. The relationship of nonspecific bronchial responsiveness to respiratory symptoms in a random population sample. Am Rev Respir Dis 1987;136:62-8.

7 Higgins BG, Britton JR, Chinn S, Cooper S, Burney PGJ, Tattersfield AE. Comparison of bronchial reactivity and peak expiratory flow variability measurements for epi-

demiologic studies. Am Rev Respir Dis 1992;145:588-93.
8 Burney P, Luczinska C, Chinn S, Jarvis D. The European Community Respiratory Health Survey. Eur Respir f 1994 7:954-60.

9 Quackenboss JJ, Lebowitz MD, Krzyzanowski M. The normal range of diurnal changes in peak expiratory flow rates. Am Rev Respir Dis 1991;143:323-30.

10 Information leaflet. Mini-Wright peak flow meter. Clement Clarke International Ltd, London: Martins Press.

11 Brand PLP, Postma DS, Kerstiens HAM, Koëter GH, and the Dutch CNSLD Study Group. Relationship of airways
hyperresponsiveness to respiratory symptoms and diurnal hyperresponsiveness to respiratory symptoms and diurnal
peak flow variation in patients with obstructive lung dispeak flow variation in patients with obstruct
ease. Am Rev Respir Dis 1991;143:916-21.

12 Wempe JB, Tammeling EP, Auffarth B, Teengs JP, Koëter GH, Postma DS. Within-day and between-day peak flow variability are differently affected by budesonide and bambuterol. In: Wempe JB. Modulation of airflow limitation. Meppel: Krips Repro, 1992:93-104.

13 American Thoracic Society. ATS statement - Snowbird workshop on standardization of spirometry. Am Rev Respir Dis 1979;119:831-8.

14 American Thoracic Society. Standardization of spirometry
- 1987 update. Am Rev Respir Dis 1987;136:1285-98. 15 Miller MR, Pincock AC. Predictive values: how should we use them? Thorax 1988;43:265-7.

16 Buist AS. Evaluation of lung function: concepts of normality. Current Pulmonol 1982;4:141-65.

17 Boezen HM, Schouten JP, Postma DS, Rijcken B. Distribution of peak expiratory flow variability by age, gender and smoking habits in a random population sample aged 20-70 yrs. Eur Respir f 1994;7:1814-20.

18 Peat JK, Toelle BG, Salome CM, Woolcock AJ. Predictive nature of bronchial responsiveness and respiratory symptoms in a one year cohort study of Sydney school-children. Eur Respir F 1993;6:662-9.

19 Clough JB, Williams JD, Holgate ST. Effects of atopy on the natural history of symptoms, peak expiratory flow, and bronchial responsiveness in 7- and 8-year-old children with cough and wheeze. Am Rev Respir Dis 1991;143: 755-60.

20 Jaakkola MS, Jaakkola JJK, Ernst P, Becklake MR. Respiratory symptoms in young adults should not be overspiratory symptoms in young adults should not be over-
looked. Am Rev Respir Dis 1993;147:359-66.

21 Sherman CB, Xu X, Speizer FE, Ferris BG Jr, Weiss ST, Dockery DW. Longitudinal lung function decline in subjects with respiratory symptoms. Am Rev Respir Dis 1992; 146:855-9.

22 Krzyzanowski M, Camilli AE, Lebowitz MD. Relationship between pulmonary function and changes in chronic respiratory symptoms. Chest 1990;98:62-70.

23 Neukirch F, Liard R, Segala C, Korobaeff M, Henry C, Cooreman J. Peak expiratory flow variability and bronchial responsiveness to methacholine. Am Rev Respir Dis 1992; 146:71-5.

24 Banjeree DK, Lee GS, Malik SK, Daly S. Underdiagnosis of asthma in the elderly. Br $\mathcal{F}$ Dis Chest 1987;81:23-9. 